Article

\title{
Bioactive Properties of Fruits and Leafy Vegetables Managed with Integrated, Organic, and Organic No-Tillage Practices in the Mediterranean Area: A Two-Year Rotation Experiment
}

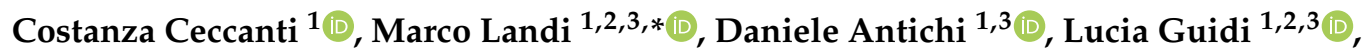 \\ Luigi Manfrini ${ }^{4}\left(\mathbb{D}\right.$, Michele Monti ${ }^{5}$, Giacomo Tosti ${ }^{6}(\mathbb{D})$ and Christian Frasconi ${ }^{1,3}$ \\ 1 Department of Agriculture, Food and Environment, University of Pisa, 56124 Pisa, Italy; \\ c.ceccanti3@studenti.unipi.it (C.C.); daniele.antichi@unipi.it (D.A.); lucia.guidi@unipi.it (L.G.); \\ christian.frasconi@unipi.it (C.F.) \\ 2 Interdepartmental Research Center Nutrafood "Nutraceuticals and Food for Health", University of Pisa, \\ Via del Borghetto 80, 56124 Pisa, Italy \\ 3 Center for Agro-Environmental Research "Enrico Avanzi”, University of Pisa, via vecchia di Marina 6, \\ San Piero a Grado, 56122 Pisa, Italy \\ 4 Department of Agricultural and Food Sciences, University of Bologna, V.le Fanin 44, 40127 Bologna, Italy; \\ luigi.manfrini@unibo.it \\ 5 Department AGRARIA, University Mediterranea of Reggio Calabria, I-89060 Reggio Calabria, Italy; \\ montim@unirc.it \\ 6 Department of Agricultural, Food and Environmental Sciences (DSA3), University of Perugia, \\ Borgo XX Giugno 74, 06121 Perugia, Italy; giacomo.tosti@gmail.com \\ * Correspondence: marco.landi@unipi.it; Tel.: +39-050-2216620
}

Received: 29 May 2020; Accepted: 11 June 2020; Published: 12 June 2020

check for updates

\begin{abstract}
The sustainability of current farming systems has been questioned in the last decades, especially in terms of the environmental impact and mitigation of global warming. Also, the organic sector, which is supposed to impact less on the environment than other more intensive systems, is looking for innovative solutions to improve its environmental sustainability. Promisingly, the integration of organic management practices with conservation agriculture techniques may help to increase environmental sustainability of food production. However, little is known about the possible impact of conservation agriculture on the content of bioactive compounds in cash crops. For this reason, a two-year rotation experiment used 7 cash crops (4 leafy vegetables and 3 fruit crops) to compare integrated (INT), organic farming (ORG), and organic no-tillage (ORG+) systems to evaluate the possible influence of cropping systems on the nutritional/nutraceutical values of the obtained fruits and leafy vegetables. The results pointed out specific responses based on the species as well as the year of cultivation. However, cultivation with the ORG+ cropping system resulted in effective obtainment of fruits and vegetables with higher levels of bioactive compounds in several cases (11 out 16 observations). The ORG+ cropping system results are particularly promising for leafy vegetable cultivation, especially when ORG+ is carried out on a multi-year basis. Aware that the obtained data should be consolidated with longer-term experiments, we conclude that this dataset may represent a good starting point to support conservation agriculture systems as a possible sustainable strategy to obtain products with higher levels of bioactive compounds.
\end{abstract}

Keywords: antioxidant activity; bioactive compounds; conservation agriculture; fruits; nutraceutic; leafy vegetables; organic farming; organic no-tillage 


\section{Introduction}

Environmental sustainability is the main concept which allows to respect and to preserve natural resources (soils, water, plant, and animal species) as well as labor capital [1,2]. In fact, sustainable agricultural practices have been adopted to satisfy the growing demand for food, thus avoiding risks connected with intensive, chemical agriculture such as nonrenewable energy consumption and, consequently, greenhouse gas (GHG) emissions, biodiversity loss in agricultural landscapes, depletion of soil organic carbon and total nitrogen pools due to excessive oxidation, leaching and translocation, water and wind erosion, and destruction of soil structure [3-5].

Integrated farming, i.e., a low-input farming system based on application of Integrated Pest Management (IPM) and reduced application of agrochemicals, has become the standard farming system in Europe since the European Union (EU) Directive 2009/128 [6] on the sustainable use of pesticides.

Organic farming includes several farming systems relying on nonuse of synthetic agrochemicals (i.e., pesticides and soluble mineral fertilizers), valorization of natural resources and biodiversity (e.g., cyclization of soil nutrients, cultivation of local plant varieties and animal breeds, use of organic amendments and green manures, application of biocontrol agents and enhancement of natural enemies), promotion of local communities, and fair agri-food systems. Organic farming relies on environmentally sound practices and is increasingly widespread worldwide, improving its competitiveness vis-à-vis standard agricultural systems, including integrated agriculture $[7,8]$. In fact, the organic farming yields are on average only estimated as $25 \%$ lower than integrated agriculture [9]. Moreover, organic farming reported higher results in terms of bioactive compounds (especially polyphenols) and antioxidant capacity compared to integrated agriculture, highlighting the effect of organic practices in improving the healthy characteristics of vegetables and fruits [10-14]. Fernandes et al. [10] reported that organic strawberries contained higher amounts of phenolic compounds when compared to conventional strawberries and that organic strawberry extracts showed higher antioxidant capacity than those from conventionally grown fruits. These authors attributed such differences to the presence of anthocyanins that were found in higher amounts in organic strawberries. Young et al. [12] reported that organic pak choi samples contained higher levels of total phenolics than conventional samples in response to insect attacks whereas no differences were found in levels of total phenolics between organic and conventional lettuce and collard samples. However, organic farming may also lead to adverse effects on soil fertility (loss of organic carbon for excessive mineralization) and greenhouse gas emissions due to integrated tillage practices (necessary for weed control, green manuring, and soil amendment incorporation) $[15,16]$. For all these reasons, the sustainability of current organic management practices has been questioned recently and the organic sector is looking for innovative solutions to improve its sustainability. A promising solution may come from the integration in organic management practices of conservation agriculture (CA) techniques, i.e., the combination between reduced soil disturbance, continuous soil cover and diversification of cropping systems according to the definition of the Food and Agriculture Organization (FAO) of the United Nations [2,17].

Conservation agriculture techniques contribute to labor savings as well as to increased yields and, at the same time, to protecting vulnerable areas from erosion and to improving soil fertility and quality, reducing also nonrenewable energy use [3,18]. Nevertheless, Colecchia et al. [19] showed that no-tillage soils induced a $23 \%$ lower yield than conventional agriculture during the first two years of agriculture conversion, and Pittelkow et al. [20] showed that no-tillage soils determined a 5-10\% lower yield than conventional soils, even though this response is very variable [20]. Furthermore, conservation agriculture increases the soil organic matter and the soil biological properties, though usually only in topsoil, and it could be a strategy for the carbon sequestration in soil and for stabilizing the $\mathrm{CO}_{2}$ in the atmosphere [21,22]. Of note, though few studies were conducted to compare bioactive properties of organic no-till crop conventional products, in most cases the highest accumulation of bioactive compounds in organic no-till crops has been demonstrated [23-25].

Conservation agriculture showed some limits when compared to other intensive or integrated systems, such as the need for adapted direct weed control, higher soil compactness and reduced water 
penetration, and additional nutrient supply which results very difficultly in the absence of synthetic fertilizers and herbicides [26]. For these reasons, conservation agriculture adopted an integrated use of cover crops, implying the crops diversification as well as the permanent soil cover [27]. In organic farming, cover crops are normally grown as green manures (i.e., to increase soil fertility and nutrient availability for cash crops, contrasting mainly with weed infestation, especially in vegetable systems that suffer more from weed competition) and, consequently, cover crop-based no-tillage may connect conservation agriculture with organic farming [3].

Although the economic and environmental effects of the organic cover crop-based no-tillage are increasingly studied in Europe, few information concerning bioactive compounds and health properties of vegetables and fruits grown according to this cultivation system in the Mediterranean area are available. The aim of this study was to compare bioactive properties of some fruit crops and leafy vegetables cultivated with a two-year rotation according to the conventional agriculture practices, standard organic one, and organic conservation ones, testing the hypothesis that cultivation technique influences the nutritional and nutraceutical values of selected crops. This study was focused on the effect of organic farming and organic cover crop-based no-tillage systems and on the effect of the year of cultivation on the levels of protein and bioactive compounds, specifically total polyphenols, chlorophylls, carotenoids, ascorbic acid, and antioxidant activity of crops (leafy vegetables and fruits) widely used in the Mediterranean area.

\section{Materials and Methods}

\subsection{Plant Material, Crop Management, and Experimental Design}

The experiment was based on the following crops: spring lettuce (Lactuca sativa L. cv. Justine), fennel (Foeniculum vulgare Mill. cv. Montebianco F1), summer lettuce (Lactuca sativa L. cv. Ballerina RZ), and savoy cabbage (Brassica oleracea var. sabauda L. cv Famosa F1) as leafy vegetables and processing tomato (Solanum lycopersicum L. cv. Ps1296), eggplant (Solanum melongena L. cv. Dalia F1), and apple (Malus domestica Borkh cv. Buckeye Gala) as fruit crops. The plant samples came from a network of experiments carried out at different sites in Italy depending on the cropping system practiced and were representative of many farming conditions in Italy (specialized field vegetable production, mixed systems with field vegetables and arable crops in rotation, and specialized fruit tree crop). All the experiments shared the same design, based on the comparison among three cropping systems with an increasing level of ecological intensification (i.e., the use of natural resources to sustain crop productivity while minimizing the use of external inputs and enhancing nutrient cycling and biology-driven processes, such as symbiotic dinitrogen fixation). The three cropping systems were (i) a control, represented by a standard integrated farming system (INT) based on conventional tillage practices (i.e., spading, rotary cultivation), mechanical and chemical weed control, chemical pesticide, and mineral fertilizer use; (ii) a standard organic cropping system (ORG) built upon the same tillage practices as INT, upon mechanical weed control, upon fertilization based on commercial solid organic fertilizers and on the use of cover crops incorporated as green manures, and upon crop protection by substances and biocontrol agents admitted according to European regulations [28,29]; and (iii) an organic conservation system (ORG+) including continuous no-tillage, use of cover crops managed as living or dead mulches, reduced organic fertilizer application cultural and thermal (i.e., flaming) weed control, and crop protection strategy as described for ORG.

Spring lettuce, fennel, summer lettuce, and savoy cabbage were grown in the facilities of the Centre for Agri-environmental Research "E. Avanzi" (CiRAA) of the University of Pisa (Pisa, Central Italy). The processing tomato was grown in the facilities of the Department of Agricultural, Food, and Environmental Sciences (FieldLab) of the University of Perugia (Peurgia, Central Italy). The eggplant was grown in the facilities of the Department AGRARIA of the University "Mediterranea" of Reggio Calabria (Reggio Calabria, Southern Italy). The apple trees were grown in the facilities of the Department of Agricultural and Food Sciences of Bologna (Bologna, Northern Italy). Agricultural practices, and type 
and splitting of fertilizers of vegetables under investigation were reported in previous studies $[3,30,31]$, whilst those of eggplant and apple are reported in Tables 1 and 2. All the experimental setups consisted of 3 randomly selected plots for each treatment.

Table 1. Agricultural practices carried out for each fruit crop in the three cropping systems.

\begin{tabular}{|c|c|c|c|c|c|c|}
\hline Crop & Level & Main Tillage & Cover Cropping & $\begin{array}{c}\text { Crop } \\
\text { Establishment }\end{array}$ & Weed & Pest \\
\hline \multirow{3}{*}{ Eggplant } & $\mathrm{INT}^{1}$ & Spading & None & Transplanting & $\begin{array}{c}\text { Chemical } \\
{ }^{2} \text { and } \\
\text { mechanical weeding }\end{array}$ & Chemical $^{4}$ \\
\hline & $\mathrm{ORG}^{1}$ & Spading & $\begin{array}{l}\text { Green manure, } \\
\text { incorporated }\end{array}$ & Transplanting & Mechanical weeding & \\
\hline & ORG $+{ }^{1}$ & No-till & $\begin{array}{l}\text { Cover crop, } \\
\text { roll-crimped }\end{array}$ & $\begin{array}{c}\text { No-till } \\
\text { transplanting }\end{array}$ & Flame weeding & \\
\hline \multirow{3}{*}{ Apple } & INT & Disk harrowing & None & & $\begin{array}{l}\text { Chemical } \\
\text { (3) and } \\
\text { mechanical weeding }\end{array}$ & Chemical $^{4}$ \\
\hline & ORG & Disk harrowing & $\begin{array}{l}\text { Green manure, } \\
\text { incorporated }\end{array}$ & & $\begin{array}{l}\text { Flame weeding on } \\
\text { the row }\end{array}$ & \\
\hline & ORG+ & No-till & $\begin{array}{l}\text { Permanent } \\
\text { cover crop }\end{array}$ & & Mowing & \\
\hline
\end{tabular}

${ }^{1}$ INT: integrated farming system, ORG: organic cropping system, ORG+: organic conservation system; ${ }^{2}$ glyphosate $30.4 \%\left(3 \mathrm{dm}^{3} \mathrm{ha}^{-1}\right)$ before the soil tillage, pendimethalin $31.7 \%\left(2.5 \mathrm{dm}^{3} \mathrm{ha}^{-1}\right)$ before the transplanting, and cycloxydim $10.5 \%\left(1.5 \mathrm{dm}^{3} \mathrm{ha}^{-1}\right)$ after the transplanting; ${ }^{3}$ glyphosate $450 \mathrm{~g} \mathrm{~L}^{-1}$ and $20 \mathrm{~L} \mathrm{ha}^{-1} ;{ }^{4}$ copper hydroxide $\left(1.5 \mathrm{~kg} \mathrm{ha}^{-1}\right)$ and imidacloprid $\left(0.5 \mathrm{~kg} \mathrm{ha}^{-1}\right)$.

Table 2. Type and splitting of fertilizers for each fruit crop in the three cropping systems.

\begin{tabular}{|c|c|c|c|}
\hline Crop & Level & Fertilizer & Dosage $\left(\mathrm{kg} \mathrm{h}^{-1}\right)$ \\
\hline \multirow{6}{*}{ Eggplant } & INT & Bovine manure ${ }^{1}$ & 70 \\
\hline & & $\mathrm{CH}_{4} \mathrm{~N}_{2} \mathrm{O}$ & 200 \\
\hline & ORG & Manure ${ }^{1}$ & 70 \\
\hline & & $\mathrm{NPK}^{2}$ fertilizer & 600 \\
\hline & ORG+ & Bovinemanure ${ }^{1}$ & 70 \\
\hline & & NPK fertilizer & 600 \\
\hline \multirow{3}{*}{ Apple } & INT & None & - \\
\hline & ORG & None & - \\
\hline & ORG+ & None & - \\
\hline
\end{tabular}

The dosage of fertilization and application splits applied in the INT system were in compliance with the maximum amount of fertilizers stated by the integrated pest management (IPM) production disciplinary of Italian Regional Governments. Conversely, the dosage of fertilization in the ORG system was set as a trade-off between the target of achieving viable yields and of keeping production costs under the threshold for profitability, and in the ORG+ system, the dosage of fertilization was conceived as the minimum amount required by the crops, differentiated according to specific crop needs, to start growing after transplanting, while the remaining amount of nutrients has been assumed to be available from soil or cover crops [30]. Details of dosage calculations are reported in Antichi et al. [3]. Except for the apple tree orchard in Bologna (that was only subdivided in different plots), all the experimental sites were split in two different fields in order to rotate the crops both in space and time and the crop rotation was replicated for two years (2015-2016). Therefore, the spatial replicates in each different cultivation site were the two adjacent fields and, in each field, the three systems (INT, ORG, and ORG+) were completely randomized with three replicates constituted by an elementary plot of $3 \mathrm{~m}$ width $\times 21 \mathrm{~m}$ length. 
The ORG and ORG+ systems included a spring and summer green manure mixture or cover crops terminated before transplanting the vegetables under investigation, and the crop rotations for each site and cropping system are reported in Table 3. Sprinkler or drip irrigation was applied to all treatments during the summer season (May-September), and no irrigation was provided after significant rain events.

\subsection{Samples}

The fruit and plant samples analyzed in this study were subsamples of the bulk samples collected randomly at harvest from the three plot replicates of farming systems present in each field in each different Italian site to assess production parameters at each site. Ten leafy plants from each plot and ten fruits in the case of tomato, eggplant, and apple were gathered for the sampling. Samples of both fruit crops and leafy vegetables were stored at $4{ }^{\circ} \mathrm{C}$ during the transport from the field to the laboratory (hour time laps), where they were processed further as follows. Fresh leaves from the leafy vegetable crops belonging to the same plot ( 3 plots per treatment) were pooled together and $20 \mathrm{~g}$ for each plot was stored at $-80^{\circ} \mathrm{C}$ using liquid nitrogen, representing a biological replicate. The collected fruits (about $1 \mathrm{~kg}$ for tomatoes, eggplants, and apples) were chopped in small pieces, and material from a single plot was pulled together; $20 \mathrm{~g}$ of material for each plot was stored at $-80^{\circ} \mathrm{C}$ using liquid nitrogen (representing a biological replicate) before biochemical analyses.

\subsection{Proteins}

Protein content was determined as described by Mollavali et al. [32] with minor modifications and by utilizing Bio-Rad reagent (Bio-Rad Laboratories s.r.l., Milan, Italy). The fresh sample (0.2 g) was added to $200 \mu \mathrm{L}$ Bio-Rad and $800 \mu \mathrm{L}$ deionized water and homogenized in a mortar. The mix was incubated for $15 \mathrm{~min}$ at room temperature, and the absorbance of the mix was measured at $595 \mathrm{~nm}$ using an Ultrospec 2100 Pro spectrophotometer (GE Healthcare Ltd, Little Chalfont, England). Comparison to a standard curve of bovine serum albumin provides a relative measurement of protein concentration that was expressed as $\mathrm{mg}$ total proteins $\mathrm{g}^{-1}$ fresh weight (FW).

\subsection{Total Phenolic Content}

Total phenolic content was determined as described by Dewanto et al. [33]. The extraction was carried out with $1.5 \mathrm{~g}$ fresh samples homogenized in $4 \mathrm{~mL}$ of $80 \%(v / v)$ methanol solution. A determined amount of supernatant was mixed with $125 \mu \mathrm{L}$ Folin-Ciocalteu reagent (Sigma-Aldrich s.r.l., Milan, Italy) and $115 \mu \mathrm{L}$ distilled water and carried out to react for $6 \mathrm{~min}$. Then, $1.25 \mathrm{~mL}$ of $7 \%(w / v) \mathrm{Na}_{2} \mathrm{CO}_{3}$ was added and samples were incubated for $90 \mathrm{~min}$. The absorbance of the solution was measured at $760 \mathrm{~nm}$. The results were expressed as mg gallic acid equivalents (GAE) per $100 \mathrm{~g}$ FW (mg GAE $100 \mathrm{~g}^{-1}$ FW).

\subsection{Chlorophylls and Carotenoids}

Chlorophyll and carotenoid analyses were performed spectrophotometrically as described by Porra et al. [34] with minor modification. The chlorophyll and carotenoid contents were exclusively determined in spring lettuce, summer lettuce, and savoy cabbage. The fresh material was extracted in $10 \mathrm{~mL}$ of $80 \%(v / v)$ acetone solution and shook overnight in the dark at $4{ }^{\circ} \mathrm{C}$. After the night, the material was homogenized and centrifuged at $10,000 \mathrm{~g}$ for $5 \mathrm{~min}$ at $-4{ }^{\circ} \mathrm{C}$. The chlorophyll and carotenoid contents were determined by collecting values of absorbance at $663 \mathrm{~nm}$ for chlorophyll $a$, at $648 \mathrm{~nm}$ for chlorophyll $b$, and at $470 \mathrm{~nm}$ for carotenoids against a blank solution of acetone $80 \%(v / v)$. Chlorophyll and carotenoid contents were expressed as $\mu \mathrm{g} \mathrm{g}^{-1} \mathrm{FW}$. 
Table 3. Crop rotation in the three different cropping systems during both experiment years for each crop under investigation, except for apple.

\begin{tabular}{|c|c|c|c|}
\hline Crop & Level & Crop Rotation & $\begin{array}{l}\text { Green Manure and Cover Crop } \\
\text { Species }\end{array}$ \\
\hline \multirow{3}{*}{ Spring lettuce } & INT & Spring lettuce-Fennel-Summer lettuce-Savoy cabbage & None \\
\hline & ORG & Spring lettuce-Summer green manure-Spring green manure-Summer lettuce-Savoy cabbage & None \\
\hline & ORG+ & Spring lettuce-Summer cover crops-Fennel-Savoy cabbage & None \\
\hline \multirow{3}{*}{ Summer lettuce } & INT & Spring lettuce-Fennel-Summer lettuce-Savoy cabbage & None \\
\hline & ORG & Spring lettuce-Summer green manure-Spring green manure-Summer lettuce-Savoy cabbage & None \\
\hline & ORG+ & Summer lettuce-Summer cover crops-Fennel-Savoy cabbage & Trifolium pratense $\mathrm{L}$ \\
\hline \multirow{3}{*}{ Savoy cabbage } & INT & Spring lettuce-Fennel-Summer lettuce-Savoy cabbage & None \\
\hline & ORG & Spring lettuce-Summer green manure-Spring green manure-Summer lettuce-Savoy cabbage & $\begin{array}{c}\text { Vicia faba var. minor Beck + Pisum } \\
\text { sativum } \mathrm{L} \text {. }\end{array}$ \\
\hline & ORG+ & Spring lettuce-Summer cover crops-Fennel-Savoy cabbage & Trifolium pratense $\mathrm{L}$. \\
\hline \multirow{3}{*}{ Fennel } & INT & Spring lettuce-Fennel-Summer lettuce-Savoy cabbage & None \\
\hline & ORG & Spring lettuce-Summer green manure-Spring green manure-Summer lettuce-Savoy cabbage & $\begin{array}{l}\text { Fagopyrum esculentum Moench + } \\
\text { Panicum miliaceum L. }+ \text { Setaria italica }(\text { L.) } \\
\text { Beauv + Vigna unguiculata (L.) Walp. }\end{array}$ \\
\hline & ORG+ & Spring lettuce-Summer cover crops-Fennel-Savoy cabbage & $\begin{array}{l}\text { Fagopyrum esculentum Moench + } \\
\text { Panicum miliaceum } \text { L. }+ \text { Setaria italica }(\text { L.) } \\
\text { Beauv + Vigna unguiculata (L.) Walp. }\end{array}$ \\
\hline \multirow{3}{*}{ Processing tomato } & INT & Durum Wheat-Processing tomato & None \\
\hline & ORG & Durum wheat-Spring green manure-Processing tomato & P. arvense $\mathrm{L} .+$ Hordeum vulgare $\mathrm{L}$. \\
\hline & ORG+ & Durum wheat/Pigeon bean intercropping-Cover crops-Processing tomato & P. arvense $\mathrm{L} .+$ Hordeum vulgare $\mathrm{L}$. \\
\hline \multirow{3}{*}{ Eggplant } & INT & Durum wheat-Eggplant & None \\
\hline & ORG & Durum wheat-Spring green manure-Eggplant & Trifolium spp. \\
\hline & ORG+ & Durum wheat-Cover crop-Eggplant & Trifolium spp. \\
\hline \multirow{3}{*}{ Apple } & INT & & None \\
\hline & ORG & & $\begin{array}{l}\text { P. sativum + Eruca sativa Mill. + } \\
\text { Sinapis alba L. }\end{array}$ \\
\hline & ORG+ & & $\begin{array}{l}\text { T. repens } \mathrm{L} .+ \text { Festuca rubra L. }+ \\
\text { Lolium perenne } \mathrm{L} .\end{array}$ \\
\hline
\end{tabular}




\subsection{Total Ascorbic Acid}

Total ascorbic acid content was determined spectrophotometrically as described by Kampfenkel et al. [35] with minor modifications. Briefly, samples were homogenized with $1 \mathrm{~mL} 6 \%$ $(w / v)$ trichloroacetic acid, stirred, and centrifuged at $15,600 \mathrm{~g}$ for $10 \mathrm{~min}$ at $4{ }^{\circ} \mathrm{C}$, and the supernatant was used for total ascorbic acid analysis. The reduction of dehydroascorbic acid to ascorbic acid was determined by an incubation with $10 \mathrm{mM}$ dithiothreitol to obtain the total ascorbic acid content, and the increase in absorbance at $525 \mathrm{~nm}$ was measured against a blank solution (without sample). Total ascorbic acid was expressed as $\mu \mathrm{g}$ ascorbic acid per gram FW ( $\left.\mu \mathrm{g} \mathrm{g}^{-1} \mathrm{FW}\right)$.

\subsection{Total Antioxidant Capacity}

Total antioxidant capacity was determined using the 2,2-diphenyl-1-picrylhydrazyl radical (DPPH) free radical scavenging assay, as described by Brand-Williams et al. [36] with minor modifications. The extraction method was the same for total phenolic determination. Sample extract was added to $990 \mu \mathrm{L} 3.12 \times 10^{-5} \mathrm{M} \mathrm{DPPH}$ and incubated in the dark for $30 \mathrm{~min}$ at room temperature. The decrease in absorbance at $515 \mathrm{~nm}$ was measured spectrophotometrically against a blank solution (without the extract). The results were expressed as mmol Trolox equivalents per $\mathrm{g} F W\left(\mathrm{mmol} \mathrm{TE} \mathrm{g}^{-1} \mathrm{FW}\right)$.

\subsection{Statistical Analysis}

Data are the mean \pm standard deviation (SD) of three replicates in each assay. Data were analyzed by two-way ANOVA using production year (2015-2016) and the three different cropping systems (INT, ORG, and ORG+) as the variability factors. When the F ratio in the two-way ANOVA interaction was not found significant, data were analyzed by one-way ANOVA using year of cultivation or cultivation systems (considering the average of two years of production) as the variability factor. Means were separated by Fisher's least significant difference (LSD) post hoc test $(p=0.05)$. All statistical analyses were conducted using GraphPad (GraphPad, La Jolla, CA, USA).

\section{Results}

\subsection{Spring Lettuce}

Figure 1 reported results of the biochemical analyses carried out in the spring lettuce in a two-year experiment according to three cropping systems (INT, ORG, and ORG+). The total phenolic content and the protein content showed no significant differences according to the three different cropping systems, whereas in one-way ANOVA with the cultivation year as the source of variability, a significant decrease of their content was reported in the year 2016 (Figure 1).

Besides, the ORG+ system allowed to obtain the significantly highest content of total chlorophylls, total carotenoids, and ascorbic acid in both experimental years and the significantly highest antioxidant activity considering the average of both experimental years, even though, in the first experimental year, it showed higher values in the INT system than the ORG and ORG+ systems (Figure 1).

\subsection{Summer Lettuce}

As showed for spring lettuce, more statistically significant differences were reported considering the experimental years as a source of variability than the cropping system also in summer lettuce (Figure 2). Total phenols, ascorbic acid, and antioxidant activity showed significantly higher results in the year 2016 than in the year 2015, whilst, conversely, protein content and carotenoids showed significantly lower results in 2016 than in 2015. Chlorophylls showed no significant differences during both experimental years. 

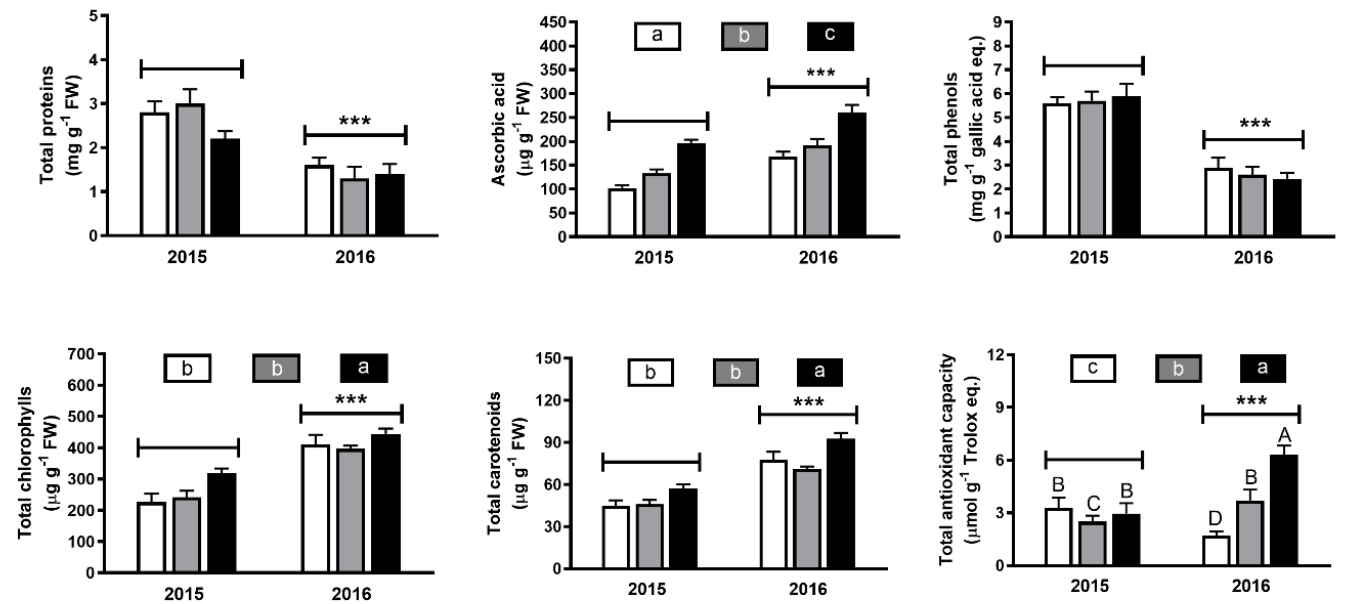

Figure 1. Total proteins, ascorbic acid, total phenols, total chlorophylls, total carotenoids, and total antioxidant activity of spring lettuce cultivated according to three different cropping system: integrated (INT), organic farming (ORG), and organic no-tillage (ORG+) in a two-year experiment. Each value is the mean $\pm \mathrm{SD}$ of three replicates. Means keyed with the same capital letter are not significantly different for $p=0.05$ following two-way ANOVA using production year (2015-2016) and the three different cropping systems (INT, ORG, and ORG+) as the variability factors. When the F ratio in the two-way ANOVA interaction was not found significant, data were analyzed by one-way ANOVA using year of cultivation or cultivation systems (considering the average of two years of production) as the variability factor. The presence of asterisks denotes significant differences for $p<0.05$ following one-way ANOVA using production year as the variability factor $(* * *<0.001)$, whilst the presence of different lowercase letters denotes significant differences for $p<0.05$ following one-way ANOVA using cropping systems as the variability factor.

Considering the means of each cropping system in both the experimental years, the ORG+ system resulted the most favorable in terms of chlorophyll and carotenoid contents, whereas the ORG system was the most significant for the antioxidant activity.

\subsection{Savoy Cabbage}

Figure 3 reports the pattern of the savoy cabbage submitted to the INT, ORG, and ORG+ systems for two consecutive years (2015-2016). Total phenolic content and antioxidant capacity showed no significant differences in the different cropping systems. On the other hand, ascorbic acid and carotenoids showed the significantly highest results in ORG+ and ORG systems whereas chlorophylls in the ORG system and proteins in the INT system consider the means of each cropping system in both experimental years.

For all compounds, means of all cropping systems with year as the source of variability reported higher results in the second experimental year (2016) compared to the first one (2015).

\subsection{Fennel}

Two-way ANOVA highlights that the ORG system showed the significantly highest content of ascorbic acid in fennel in 2016 (Figure 4). Significant differences among the experimental years were noted in the protein and in the total phenolic content, reporting the highest and lowest results in the year 2016, respectively (Figure 4). Considering the means of each cropping system in both experimental years, the INT system allowed to obtain the significantly highest amount of total phenols and proteins. The antioxidant capacity showed no significant differences among years or cropping systems. 


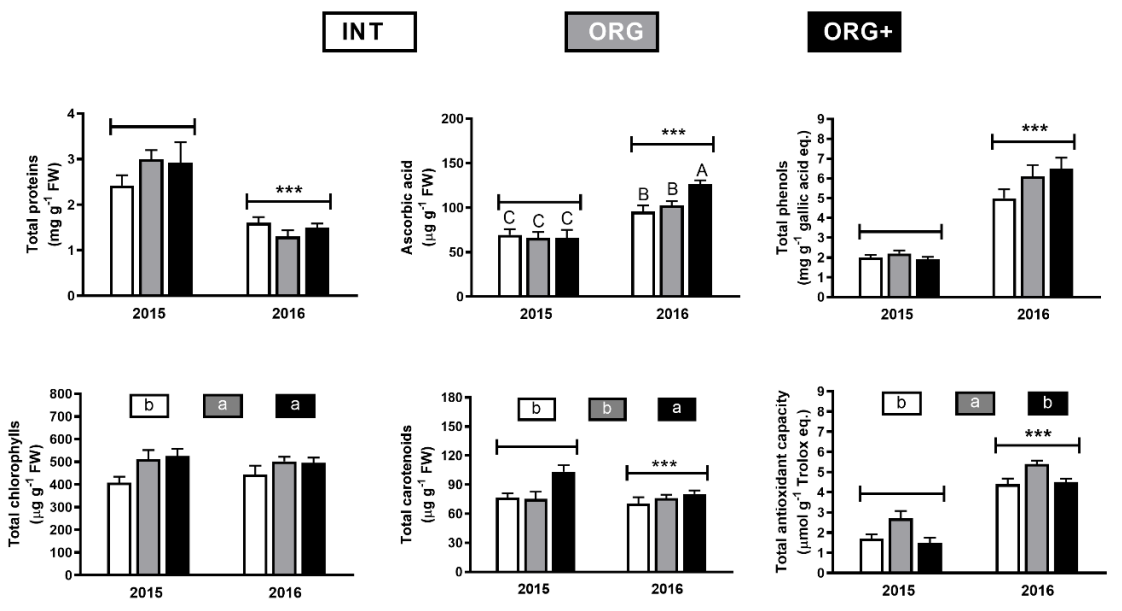

Figure 2. Total proteins, ascorbic acid, total phenols, total chlorophylls, total carotenoids, and total antioxidant activity of summer lettuce cultivated according to three different cropping system: integrated (INT), organic farming (ORG), and organic no-tillage (ORG+) in a two-year experiment. Each value is the mean $\pm \mathrm{SD}$ of three replicates. Means keyed with the same capital letter are not significantly different for $p=0.05$ following two-way ANOVA using production year (2015-2016) and the three different cropping systems (INT, ORG, and ORG+) as the variability factors. When the F ratio in the two-way ANOVA interaction was not found significant, data were analyzed by one-way ANOVA using year of cultivation or cultivation systems (considering the average of two years of production) as the variability factor. The presence of asterisks denotes significant differences for $p<0.05$ following one-way ANOVA using production year as the variability factor ${ }^{* * *} p<0.001$ ), whilst the presence of different lowercase letters denotes significant differences for $p<0.05$ following one-way ANOVA using cropping systems as the variability factor.

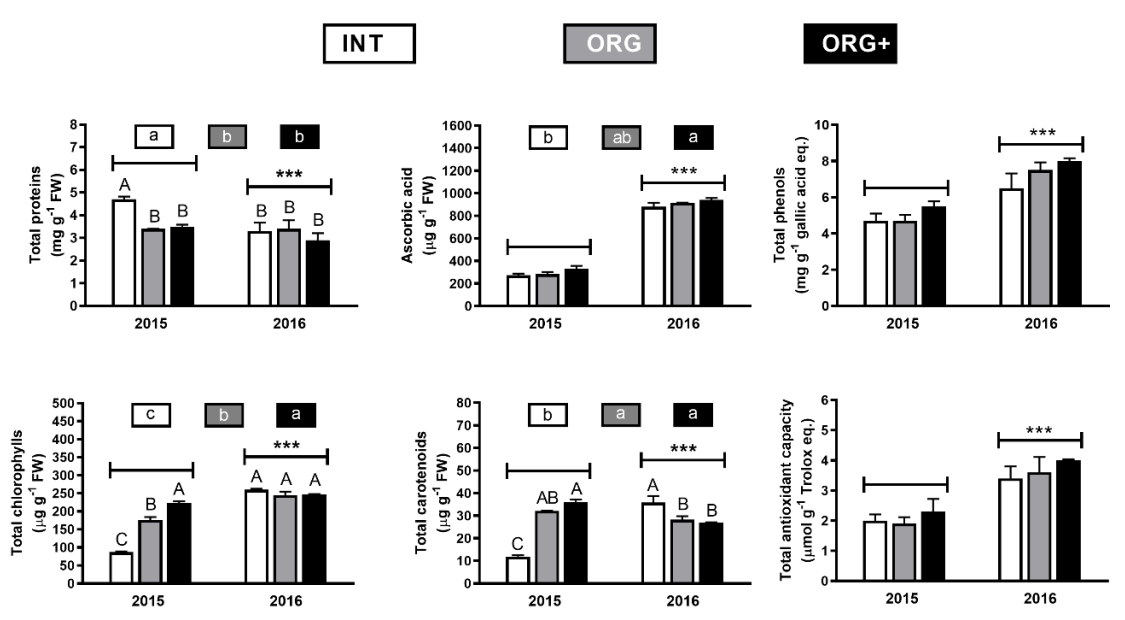

Figure 3. Total proteins, ascorbic acid, total phenols, total chlorophylls, total carotenoids, and total antioxidant activity of savoy cabbage cultivated according to three different cropping system: integrated (INT), organic farming (ORG), and organic no-tillage (ORG+) in a two-year experiment. Each value is the mean $\pm \mathrm{SD}$ of three replicates. Means keyed with the same capital letter are not significantly different for $p=0.05$ following two-way ANOVA using production year (2015-2016) and the three different cropping systems (INT, ORG, and ORG+) as the variability factors. When the F ratio in the two-way ANOVA interaction was not found significant, data were analyzed by one-way ANOVA using year of cultivation or cultivation systems (considering the average of two years of production) as the variability factor. The presence of asterisks denotes significant differences for $p<0.05$ following one-way ANOVA using production year as the variability factor $(* * *<0.001)$, whilst the presence of different lowercase letters denotes significant differences for $p<0.05$ following one-way ANOVA using cropping systems as the variability factor. 

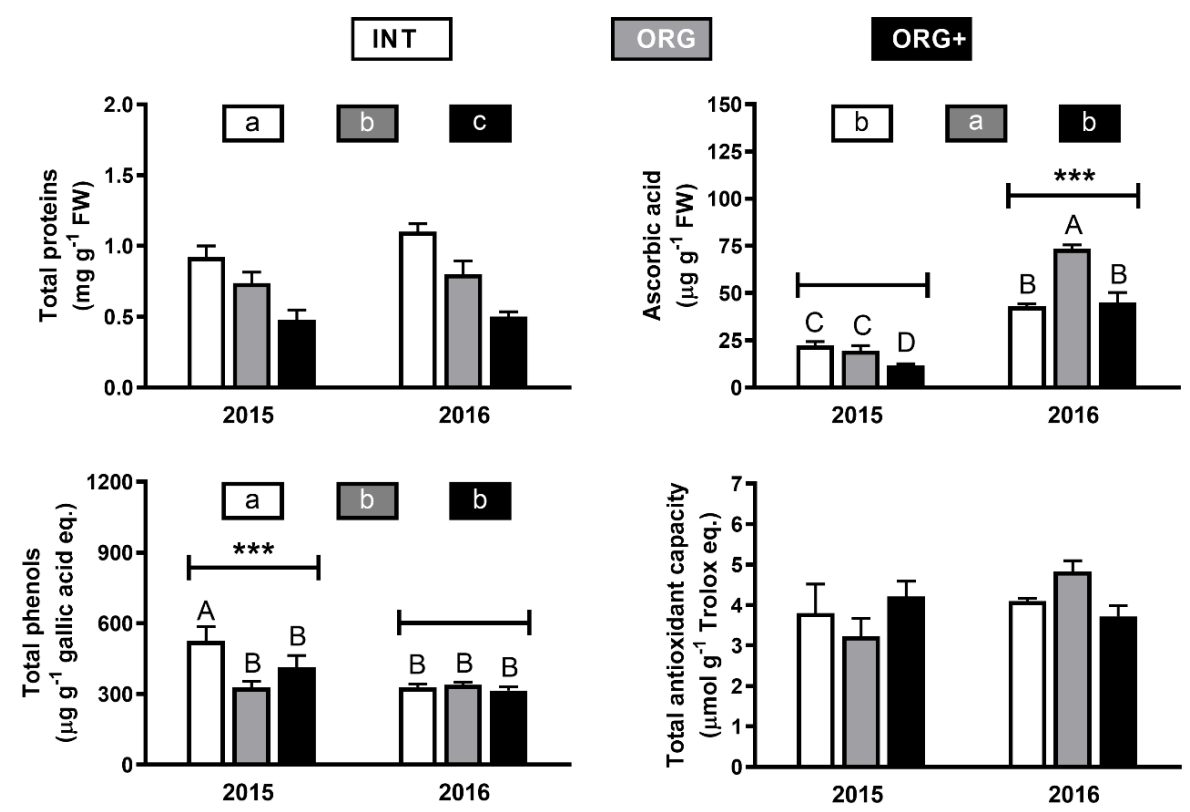

Figure 4. Total proteins, ascorbic acid, total phenols, and total antioxidant activity of fennel cultivated according to three different cropping system: integrated (INT), organic farming (ORG), and organic no-tillage $(\mathrm{ORG}+)$ in a two-year experiment. Each value is the mean $\pm \mathrm{SD}$ of three replicates. Means keyed with the same capital letter are not significantly different for $p=0.05$ following two-way ANOVA using production year (2015-2016) and the three different cropping systems (INT, ORG, and ORG+) as the variability factors. When the F ratio in the two-way ANOVA interaction was not found significant, data were analyzed by one-way ANOVA using year of cultivation or cultivation systems (considering the average of two years of production) as the variability factor. The presence of asterisks denotes significant differences for $p<0.05$ following one-way ANOVA using production year as the variability factor $\left({ }^{* * *} p<0.001\right)$, whilst the presence of different lowercase letters denotes significant differences for $p<0.05$ following one-way ANOVA using cropping systems as the variability factor.

\subsection{Processing Tomato}

Figure 5 reports the pattern of processing tomato submitted to the INT, ORG, and ORG+ systems for two consecutive years (2015-2016).

The ascorbic acid and the total antioxidant activity showed the significantly highest results in the INT and ORG+ systems in the year 2016 (Figure 5). Considering the means of both the years, the significantly highest results were reported in the second year of the experiment for all the biochemical analyses, whilst, considering the means of each cropping systems, the significantly highest ascorbic acid content was reported in the INT and ORG+ systems and the significantly highest phenolic content was reported in the ORG and ORG+ systems (Figure 5).

\subsection{Eggplant}

Figure 6 reports the pattern of eggplant submitted to the INT, ORG and ORG+ systems for two consecutive years (2015-2016).

No significant differences among different cropping systems were found in the protein and total phenolic contents (Figure 6). In two-way ANOVA, ascorbic acid reported the significant highest results in the ORG and ORG+ systems during the first experimental year, whilst the total antioxidant activity was the highest in the ORG system of the same year (Figure 6). Considering the means of both the years regardless of the cropping systems, significant differences were showed, reporting lower results in the second year compared to 2015. 

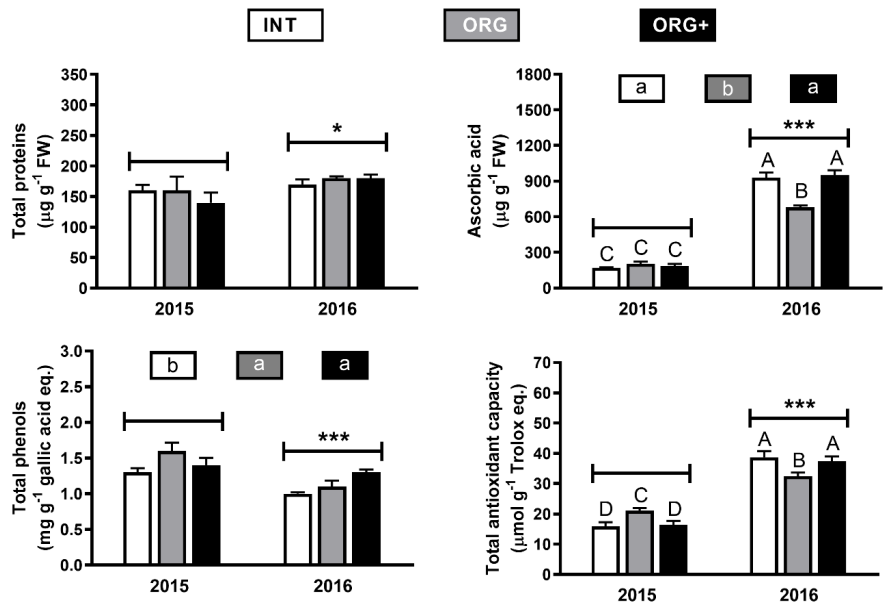

Figure 5. Total proteins, ascorbic acid, total phenols, and total antioxidant activity of processing tomato cultivated according to three different cropping system: integrated (INT), organic farming (ORG), and organic no-tillage $(\mathrm{ORG}+)$ in a two-year experiment. Each value is the mean $\pm \mathrm{SD}$ of three replicates. Means keyed with the same capital letter are not significantly different for $p=0.05$ following two-way ANOVA using production year (2015-2016) and the three different cropping systems (INT, ORG, and ORG+) as the variability factors. When the F ratio in the two-way ANOVA interaction was not found significant, data were analyzed by one-way ANOVA using year of cultivation or cultivation systems (considering the average of two years of production) as the variability factor. The presence of asterisks denotes significant differences for $p<0.05$ following one-way ANOVA using production year as the variability factor ${ }^{*} p<0.05$ and ${ }^{* * *} p<0.001$ ), whilst the presence of different lowercase letters denotes significant differences for $p<0.05$ following one-way ANOVA using cropping systems as the variability factor.
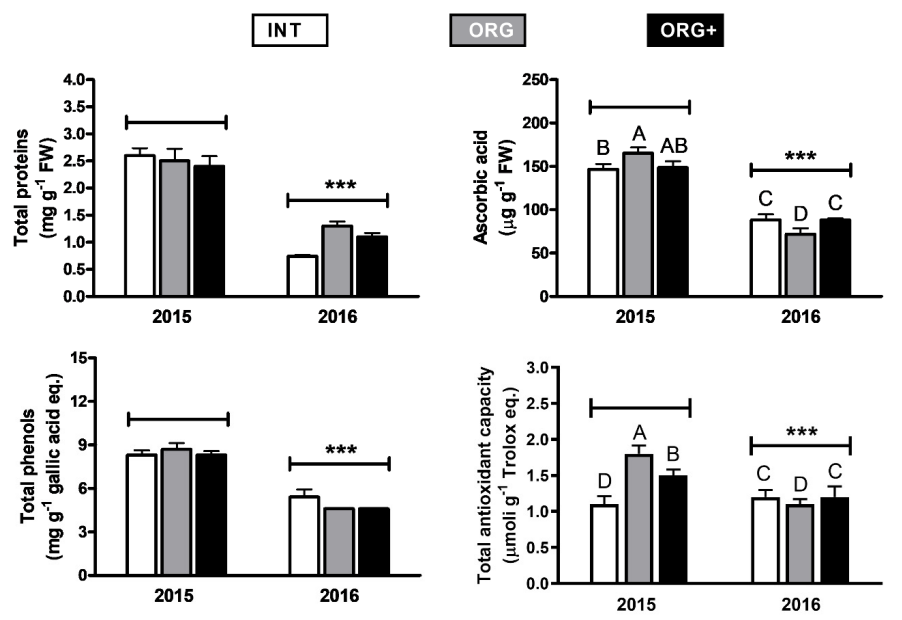

Figure 6. Total proteins, ascorbic acid, total phenols, and total antioxidant activity of eggplant cultivated according to three different cropping system: integrated (INT), organic farming (ORG), and organic no-tillage $(\mathrm{ORG}+)$ in a two-year experiment. Each value is the mean $\pm \mathrm{SD}$ of three replicates. Means keyed with the same capital letter are not significantly different for $p=0.05$ following two-way ANOVA using production year (2015-2016) and the three different cropping systems (INT, ORG, and ORG+) as the variability factors. When the F ratio in the two-way ANOVA interaction was not found significant, data were analyzed by one-way ANOVA using year of cultivation or cultivation systems (considering the average of two years of production) as the variability factor. The presence of asterisks denotes significant differences for $p<0.05$ following one-way ANOVA using production year as the variability factor $\left({ }^{* * *} p<0.001\right)$, whilst the presence of different lowercase letters denotes significant differences for $p<^{\prime} 0.05$ following one-way ANOVA using cropping systems as the variability factor. 


\subsection{Apple}

In apple, statistically significant differences were reported in all the biochemical analyses only considering the means of the experimental years results, reporting the lowest values in the 2016 (Figure 7). No significant differences were reported in terms of cropping systems (Figure 7).
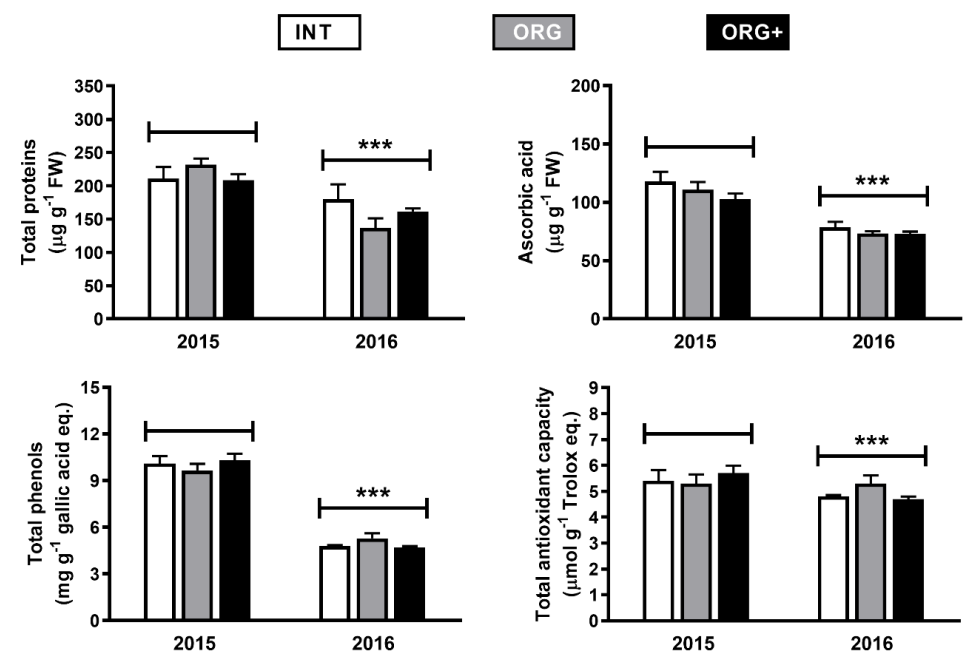

Figure 7. Total proteins, ascorbic acid, total phenols, and total antioxidant activity of apple cultivated according to three different cropping system: integrated (INT), organic farming (ORG), and organic no-tillage $(\mathrm{ORG}+)$ in a two-year experiment. Each value is the mean $\pm \mathrm{SD}$ of three replicates. Means keyed with the same capital letter are not significantly different for $p=0.05$ following two-way ANOVA using production year (2015-2016) and the three different cropping systems (INT, ORG, and ORG+) as the variability factors. When the F ratio in the two-way ANOVA interaction was not found significant, data were analyzed by one-way ANOVA using year of cultivation or cultivation systems (considering the average of two years of production) as the variability factor. The presence of asterisks denotes significant differences for $p<0.05$ following one-way ANOVA using production year as the variability factor (*** $p<0.001$ ), whilst the presence of different lowercase letters denotes significant differences for $p<0.05$ following one-way ANOVA using cropping systems as the variability factor.

\section{Discussion}

Overall, total protein amount was not influenced by the agricultural practices except for savoy cabbage and fennel in which it decreased in products cultivated in both the ORG and ORG+ techniques. The most important change in protein amount was detected in relation to the years of cultivation with a strong decrease observed in all fruit and vegetables at the second year of cultivation with the exception of fennel in which no changes were recorded. It is worth to notice that, in this vegetable as in processing tomato and apple fruits, the protein amount is much lower as compared to other vegetables and fruits analyzed in this experiment. Also, Bilalis et al. [37] found no significant differences between the tillage systems concerning the protein content. However, the examined species do not represent a source of protein in human diet, and therefore, the protein amount in these crops is very marginal. Most of the works regarding the influence of the tillage are concerned with grain crops. Also, in those cases, the protein amount is higher in integrated tillage compared to minimum tillage [38,39].

Phenolic compounds were significantly influenced by agronomical techniques only in fennel and processing tomato fruits, but, while in the latter the phenol content was significantly increased in ORG and ORG+, in fennel, the INT system produced the product with the highest phenol content. Generally, phenolic compounds were not affected by conventional or organic systems, as reported in most part of the examined species of our study [40], even though contrasting results are reported in the literature. In fact, some authors also reported that vegetables cultivated in organic farming contained higher levels of bioactive compounds than those cultivated in conventional farming, since the lack of herbicide 
and fertilizers in organic farming forces the plant to respond to environmental stressors, thereby activating the stress-triggered secondary metabolism [23-25]. Then, differences were found in relation to the year of cultivation with a higher value of phenol amount observed in summer lettuce and savoy cabbage in 2016 compared to 2015, while the highest values in the other products were detected in the yield obtained in 2015. Gaafar and Salama [41] carried out a study in which the effects of three different treatments on phytochemicals of fennel were evaluated: (i) conventional chemical nitrogen, phosphorus, potassium (NPK) fertilization; (ii) sum of organic and chemical NPK fertilization; and (iii) sum of bioorganic and chemical NPK fertilization. Total phenolic and total ascorbic acid contents were higher in the second and in the third fertilization systems than in the conventional one [41]. On the other hand, Zambrano-Moreno et al. [42] reported that the higher phenolic content of eggplant was showed in the organic system compared to conventional one (0.64 and $0.77 \mathrm{mg} \mathrm{GAE} \mathrm{g}^{-1}$ in conventional and organic systems, respectively). In our experiment, phenols in eggplant did not change in relation to the agricultural practices but the amount found in the fruits was much higher than that found by Gaafar and Salama [41].

The higher bioactive compound content found in the ORG or ORG+ systems compared to the INT system could be due to the tendency of those systems to provide, on average, lesser levels of nutrients than INT practices, thus resulting in an increase in secondary metabolite synthesis. In addition, organic practices for crop production, owing to the limited options for plant protection, can likely improve the antioxidant system of the plant's defense-response mechanism [43], thus increasing the phytochemical content [44]. However, the topic is somewhat controversial. Young et al. [12] reported an increase in phenol compounds in organic pak choi samples associated with a greater attack on the plants in organic plots by flea beetles. These authors concluded that an organic production method alone did not enhance biosynthesis of phytochemicals in lettuce and collards but that it provided an increased opportunity for insect attack, resulting in a higher level of total phenolic agents in pak choi. Conversely, Heimler et al. [14] showed that the total phenolic content and the antioxidant activity were higher in the INT system compared to the ORG system.

Ascorbic acid content was higher in the products obtained in the year 2016 except for eggplant. No differences in relation to the agronomical techniques were found for eggplant, processing tomato, and apple, while a decrease in leaf spring lettuce produced by the ORG and ORG+ techniques was recorded. On the contrary, an enhancement in ascorbic acid amount was found in leaves of summer lettuce and savoy cabbage produced with the ORG+ technique and in fennel from ORG. The results evidenced a species-specific response of the analyzed crop species, as already noted in literature. da Silva et al. [23] showed higher value of ascorbic acid in organic not-till loose-leaf lettuce than in conventional lettuce, reporting $429 \mu \mathrm{g} \mathrm{g}^{-1} \mathrm{FW}$ in the ORG+ system and $297 \mu \mathrm{g} \mathrm{g}{ }^{-1} \mathrm{FW}$ in the INT system, as reported for summer lettuce in our experiments. However, those authors found a higher content in ascorbic acid in the leaf of lettuce than that found in our experiment.

Chlorophylls and carotenoids were only determined in leafy vegetables and, in general, both chlorophyll and carotenoid contents were higher in products obtained in 2016. Differently to other compounds, the ORG and ORG+ techniques enhanced the amount of chlorophylls and carotenoids in all the studied leafy vegetables.

Certainly, the year of the cultivation had a strong influence on phytochemicals in fruit and vegetables in relation to the weather conditions already reported in Antichi et al. [3]. Most of the species under investigation reported higher results in the second experimental year compared to the first year, which might therefore be dependent on the differences of climatic conditions and on soil modification due to protraction of treatments over the same experimental area. In their study, Bottenberg et al. [45] grew cabbage (Brassica oleracea var. capitata L. cv. "Market Prize") for two experimental years according to four cropping systems: (i) conventional system; (ii) organic reduced tillage with cereal rye; (iii) organic reduced tillage with rye residue from spring-killed, autumn-planted cereal rye, mixed with a spring-planted red clover; and (iv) excelsior mulch (no-tillage) [45]. The authors of this study showed that the reduced tillage with cereal rye reported $0.96 \mathrm{~kg} \mathrm{plant}^{-1}$, a considerable yield compared to that 
of conventional system $\left(1.06 \mathrm{~kg} \mathrm{plant}^{-1}\right.$ in the reduced tillage and $1.04 \mathrm{~kg} \mathrm{plant}^{-1}$ in the conventional system). During the second experimental year, the yield of the reduced tillage decreased compared to a conventional system [44]. No phytochemical investigation was reported about the ORG or ORG+ systems in a two-year experiment. However, the study of Bottenberg et al. [45] could be in contrast with our findings since major yield may relate to great environmental factors able to increase the yield as well as the bioactive properties of the plants. Further researches are necessary to verify which elements influenced the bioactive properties in plants submitted to different cropping systems, especially to organic cover-crop-based no-tillage, a "new" cropping system; still, little is studied in terms of bioactive properties and in two-year experiments.

The results of the present experiment offer evidence that ORG+ products yield in several cases higher levels of bioactive compounds with respect to INT- and ORG-grown products. However, the aforementioned results also pointed out specific responses based on the species as well as on the year of cultivation. Therefore, in order to draw some final conclusions, in Figure 8, a schematization of the overall effect of cultivation system and year of cultivation on the total amount of screened bioactive compounds in all the tested crop species (grouped together) is provided. The attempt was also to discern possible differences between fruits and leafy vegetables in terms of effectiveness of the ORG+ treatment.

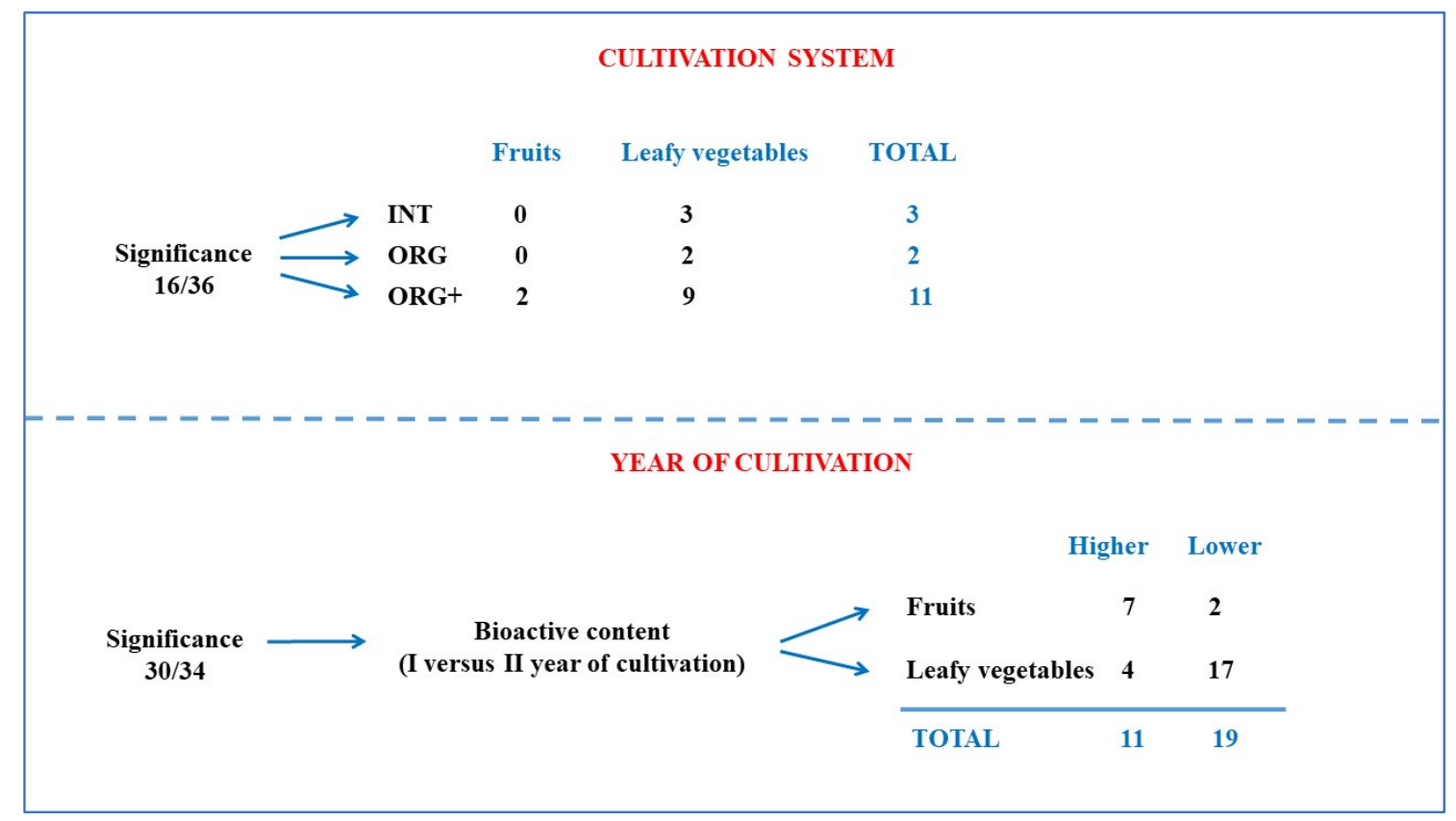

Figure 8. The effects of cultivation system (upper side) and production year (lower side) in fruit crops (tomato, eggplant, and apple) and leafy vegetables (spring and summer lettuce, savoury cabbage, and fennel) cultivated according to three different cropping system: integrated (INT), organic farming $(\mathrm{ORG})$, and organic no-tillage (ORG+) in a two year-rotation experiment. Data indicate the number of observations related to bioactive compounds (chlorophyll, carotenoid, total phenol, and ascorbic acid content) and total antioxidant activity for which the cultivation system allows to obtain the products with the highest bioactive compound levels (upper side).

On the basis of 16 observations for which the cultivation systems resulted significantly different in terms of bioactive compound yield in our tested crop species, the first notable result is that the ORG+ cropping system resulted better than INT and ORG in 11 out 16 cases. In particular, leafy vegetables got the greatest benefits in terms of bioactive compound yield from the ORG+ cropping system (9 out 11 observations).

Considering the year of cultivation, it resulted seriously impactful to our experiment (30 out 34 observations related to bioactive compounds and total antioxidant capacity considered in our tested crop species). However, when considering years I versus II of cultivation, we did not 
observe a consistent effect exerted by the cultivation year: in 11 cases, our crops showed higher nutraceutical value (in terms of bioactive compounds and total antioxidant capacity), whilst in 19 cases, they accounted for lower levels. It also worth to be highlighted the contrasting effect attributable to the crop source: the levels of bioactive compounds and total antioxidant capacity were higher in fruit species in the first year of cultivation (7 out 9 cases), whilst in leafy vegetables, we observed a higher nutraceutical values in products obtained in the second year (17 out 21 observations).

To conclude, the results provided in this two-year rotation experiment in which INT, ORG, and ORG+ were compared in 7 cash crops (4 leafy vegetables and 3 fruit crops) highlight that cultivation with the ORG+ cropping system is effective in obtaining products with higher levels of bioactive compounds in several cases. The ORG+ cropping system is particularly promising for leafy vegetable cultivation, especially when ORG+ is carried out on a multi-year basis.

Author Contributions: Conceptualization, C.F., D.A., G.T., L.M., and M.M.; methodology, C.C., M.L., and L.G.; validation, C.C., M.L., and L.G.; formal analysis, C.C. and M.L.; resources, C.F., D.A., G.T., L.M., and M.M; data curation, C.F., D.A., G.T., L.M., and M.M; writing-original draft preparation, C.C., M.L., and L.G.; writing-review and editing C.F., D.A., G.T., L.M., and M.M.; project administration, C.F.; funding acquisition, C.F. All authors have read and agreed to the published version of the manuscript.

Funding: This research was carried out within the project SMOCA “Smart Management of Organic Conservation Agriculture" (http://smoca.agr.unipi.it/) funded by the Italian Ministry of University and Research (MIUR) within the programs FIRB-2013 (Future in Research) and MIUR-FIRB13 (project number: RBFR13L8J6).

Acknowledgments: The authors would like to thank all the technicians who were involved in the project at the FieldLab in Papiano (PG, Italy), AUB-DISTAL (BO, Italy), Department AGRARIA (RC, Italy) and at CiRAA in San Piero a Grado (PI, Italy) for their invaluable help with the field work.

Conflicts of Interest: The authors declare no conflict of interest.

\section{References}

1. Goodland, R. Environmental sustainability in agriculture: Diet matters. Ecol. Econ. 1997, 23, 189-200. [CrossRef]

2. Peigné, J.; Ball, B.C.; Roger-Estrade, J.; David, C. Is conservation tillage suitable for organic farming? A review. Soil Use Manage. 2007, 23, 129-144. [CrossRef]

3. Antichi, D.; Sbrana, M.; Martelloni, L.; Abou Chehade, L.; Fontanelli, M.; Raffaelli, M.; Mazzoncini, M.; Peruzzi, A.; Frasconi, C. Agronomic performances of organic field vegetables managed with conservation agriculture techniques: A study from central Italy. Agronomy 2019, 9, 810. [CrossRef]

4. Mazzoncini, M.; Antichi, D.; Di Bene, C.; Risaliti, R.; Petri, M.; Bonari, E. Soil carbon and nitrogen changes after 28 years of no-tillage management under Mediterranean conditions. Eur. J. Agron. 2016, 77, $156-165$. [CrossRef]

5. Petit, S.; Firbank, L. Predicting the risk of losing parcels of semi-natural habitat to integrated agriculture. Agr. Ecosyst. Environ. 2006, 115, 277-280. [CrossRef]

6. EUR-Lex. European Union Directive 2009/128/EC of the European Parliament and of the Council of 21 October 2009 Establishing a Framework for Community Action to Achieve the Sustainable Use of Pesticides. Available online: https://eur-lex.europa.eu/legal-content/EN/ALL/?uri=celex\%3A32009L0128 (accessed on 9 June 2020).

7. Paull, J. From France to the World: The International Federation of Organic Agriculture Movements (IFOAM). JSRP 2010, 1, 93-102.

8. Darnhofer, I.; Lindenthal, T.; Bartel-Kratochvil, R.; Zollitsch, W. Conventionalisation of organic farming practices: From structural criteria towards an assessment based on organic principles. A review. Agron. Sustain. Dev. 2010, 30, 67-81. [CrossRef]

9. Seufert, V.; Ramankutty, N.; Foley, J.A. Comparing the yields of organic and conventional agriculture. Nature 2012, 485, 229-232. [CrossRef]

10. Fernandes, V.C.; Domingues, V.F.; de Freitas, V.; Delerue-Matos, C.; Mateus, N. Strawberries from integrated pest management and organic farming: Phenolic composition and antioxidant properties. Food Chem. 2012, 134, 1926-1931. [CrossRef] 
11. Oliveira, A.B.; Moura, C.F.; Gomes-Filho, E.; Marco, C.A.; Urban, L.; Miranda, M.R.A. The impact of organic farming on quality of tomatoes is associated to increased oxidative stress during fruit development. PLOS ONE 2013, 8, e56354. [CrossRef]

12. Young, J.E.; Zhao, X.; Carey, E.E.; Welti, R.; Yang, S.S.; Wang, W. Phytochemical phenolics in organically grown vegetables. Mol. Nutr. Food Res. 2005, 49, 1136-1142. [CrossRef] [PubMed]

13. Asami, D.K.; Hong, Y.J.; Barrett, D.M.; Mitchell, A.E. Comparison of the total phenolic and ascorbic acid content of freeze-dried and air-dried marionberry, strawberry, and corn grown using conventional, organic, and sustainable agricultural practices. J. Agric. Food Chem. 2003, 51, 1237-1241. [CrossRef] [PubMed]

14. Heimler, D.; Vignolini, P.; Arfaioli, P.; Isolani, L.; Romani, A. Conventional, organic and biodynamic farming: Differences in polyphenol content and antioxidant activity of Batavia lettuce. J. Sci. Food Agric. 2012, 92, 551-556. [CrossRef] [PubMed]

15. Kirchmann, H.; Thorvaldsson, G. Challenging targets for future agriculture. European J. Agron. 2000, 12, 145-161. [CrossRef]

16. Trewavas, A. A critical assessment of organic farming-and-food assertions with particular respect to the UK and the potential environmental benefits of no-till agriculture. Crop. Prot. 2004, 23, 757-781. [CrossRef]

17. Casagrande, M.; Peigné, J.; Payet, V. Organic farmers' motivations and challenges for adopting conservation agriculture in Europe. Org. Agric. 2016, 6, 281-295. [CrossRef]

18. Hobbs, P.R.; Sayre, K.; Gupta, R. The role of conservation agriculture in sustainable agriculture. Philos. T. R. Soc. B 2008, 363, 543-555. [CrossRef]

19. Colecchia, S.A.; De Vita, P.; Rinaldi, M. Effects of tillage systems in durum wheat under rainfed Mediterranean conditions. Cereal Res. Commun. 2015, 43, 704-716. [CrossRef]

20. Pittelkow, C.M.; Linquist, B.A.; Lundy, M.E.; Liang, X.; van Groenigen, K.J.; Lee, J.; van Gestel, N.; Six, J.; Venterea, R.T.; van Kessel, C. When does no-till yield more? A global meta-analysis. Field Crop. Res. 2015, 183, 156-168. [CrossRef]

21. Bissett, A.; Richardson, A.E.; Baker, G.; Kirkegaard, J.; Thrall, P.H. Bacterial community response to tillage and nutrient additions in a long-term wheat cropping experiment. Soil Biol. Biochem. 2013, 58, 281-292. [CrossRef]

22. Kassam, A.; Friedrich, T.; Shaxson, F.; Pretty, J. The spread of conservation agriculture: Justification, sustainability and uptake. Int. J. Agr. Sustain. 2009, 7, 292-320. [CrossRef]

23. da Silva, E.M.N.; Ferreira, R.L.F.; Araújo Neto, S.E.D.; Tavella, L.B.; Solino, A.J. Qualidade de alface crespa cultivada em sistema orgânico, convencional e hidropônico. Hortic. Bras. 2011, 29, 242-245. [CrossRef]

24. Hallmann, E.; Kazimierczak, R.; Marszałek, K.; Drela, N.; Kiernozek, E.; Toomik, P.; Matt, D.; Luik, A.; Rembiałkowska, E. The nutritive value of organic and conventional white cabbage (Brassica oleracea L. Var. Capitata) and anti-apoptotic activity in gastric adenocarcinoma cells of sauerkraut juice produced therof. J. Agric. Food Chem. 2017, 65, 8171-8183. [CrossRef] [PubMed]

25. Hallmann, E. The influence of organic and conventional cultivation systems on the nutritional value and content of bioactive compounds in selected tomato types. J. Sci. Food Agric. 2012, 92, 2840-2848. [CrossRef] [PubMed]

26. Gianessi, L.P. Importance of Herbicides for No-Till Agriculture in South America. Int. Pestic. Benefits Case Study 2014, 111, 1-4.

27. FAO. Conservation Agriculture. Available online: http://www.fao.org/conservation-agriculture/en/ (accessed on 9 June 2020).

28. EUR-Lex. Council Regulation (EC) No 834/2007 of 28 June 2007 on Organic Production and Labelling of Organic Products and Repealing Regulation (EEC) No 2092/91. Available online: https:/eur-lex.europa.eu/ legal-content/EN/TXT/PDF/?uri=CELEX:32007R0834\&from=IT (accessed on 9 June 2020).

29. EUR-Lex. Commission Regulation (EC) No 889/2008 of 5 September 2008 Laying Down Detailed Rules for the Implementation of Council Regulation (EC) No 834/2007 on Organic Production and Labelling of Organic Products with Regard to Organic Production, Labelling and Control. Available online: https: //eur-lex.europa.eu/legal-content/EN/TXT/PDF/?uri=CELEX:32008R0889\&from=IT (accessed on 9 June 2020).

30. Bosco, S.; Volpi, I.; Antichi, D.; Ragaglini, G.; Frasconi, C. Greenhouse gas emissions from soil cultivated with vegetables in crop rotation under Integrated, organic and organic conservation management in a Mediterranean environment. Agron. 2019, 9, 446. [CrossRef] 
31. Tosti, G.; Benincasa, P.; Farneselli, M.; Guiducci, M.; Onofri, A.; Tei, F. Processing Tomato-Durum Wheat Rotation under Integrated, Organic and Mulch-Based No-Tillage Organic Systems: Yield, N Balance and N Loss. Agronomy 2019, 9, 718. [CrossRef]

32. Mollavali, M.; Bolandnazar, S.A.; Schwarz, D.; Rohn, S.; Riehle, P.; Zaare Nahandi, F. Flavonol glucoside and antioxidant enzyme biosynthesis affected by mycorrhizal fungi in various cultivars of onion (Allium cepa L.). J. Agric. Food Chem. 2016, 64, 71-77. [CrossRef]

33. Dewanto, V.; Adom, K.K.; Liu, R.H. Thermal processing enhances the nutritional value of tomatoes by increasing total antioxidant activity. J. Agric. Food Chem. 2002, 50, 3010-3014. [CrossRef]

34. Porra, R.J.; Thompson, W.A.; Kriedemann, P.E. Determination of accurate extinction coefficients and simultaneous equations for assaying chlorophylls a and b extracted with four different solvents: Verification of the concentration of chlorophyll standards by atomic absorption spectroscopy. Biochim. Biophys. Acta Bioenerg. 1989, 975, 384-394. [CrossRef]

35. Kampfenkel, K.; Van Montagu, M.; Inzé, D. Extraction and determination of ascorbate and dehydroascorbate from plant tissue. Anal. Biochem. 1995, 225, 165-167. [CrossRef] [PubMed]

36. Brand-Williams, W.; Cuvelier, M.E.; Berset, C. Use of a free radical method to evaluate antioxidant activity. Lwt-Food Sci. Technol. 1995, 28, 25-30. [CrossRef]

37. Bilalis, D.; Karkanis, A.; Patsiali, S.; Agriogianni, M.; Konstantas, A.; Triantafyllidis, V. Performance of wheat varieties (Triticum aestivum L.) under conservation tillage practices in organic agriculture. Not. Bot. Horti Agrobo. 2011, 39, 28-33. [CrossRef]

38. Simunic, R.; Zimer, R.; Dernik, A.; Brnovic, M.; Jelosek, D. Yield Components and Quality of Maize at Four Crop Production Levels. In Proceedings of the 41st Croatian and 1st International Symposium on Agriculture, Opatija, Croatia, 3-17 February 2006; pp. 481-483.

39. De Vita, P.; Di Paolo, E.; Fecondo, G.; Di Fonzo, N.; Pisante, M. No-tillage and Conventional Tillage Effects on Durum Wheat Yield, Grain Quality and Soil Moisture Content in Southern Italy. Soil Till. Res. 2007, 92, 69-78. [CrossRef]

40. Mazzoncini, M.; Antichi, D.; Silvestri, N.; Ciantelli, G.; Sgherri, C. Organically vs conventionally grown winter wheat: Effects on grain yield, technological quality, and on phenolic composition and antioxidant properties of bran and refined flour. Food Chem. 2015, 175, 445-451. [CrossRef]

41. Gaafar, A.A.; Salama, Z.A.; El-Baz, F.K. Characterization of phenolics in two cultivars of broccoli and fennel grown under organic and bio-organic fertilization by high performance liquid chromatography (HPLC). Nat. Prod. 2013, 9, 367-374.

42. Zambrano-Moreno, E.L.; Chávez-Jáuregui, R.N.; Plaza, M.D.L.; Wessel-Beaver, L. Phenolic content and antioxidant capacity in organically and conventionally grown eggplant (Solanum melongena) fruits following thermal processing. Food Sci. Technol. 2015, 35, 414-420. [CrossRef]

43. Carbonaro, M.; Mattera, M. Polyphenoloxidase activity and polyphenol levels in organically and conventionally grown peach (Prunus persica L., cv. Regina bianca) and pear (Pyrus communis L., cv. Williams). Food Chem. 2001, 72, 419-424. [CrossRef]

44. Leccese, A.; Bureau, S.; Reich, M.; Renard, M.G.C.C.; Audergon, J.M.; Mennone, C.; Bartolini, S.; Viti, R. Pomological and Nutraceutical Properties in Apricot Fruit: Cultivation Systems and Cold Storage Fruit Management. Plant. Food Hum. Nutr. 2010, 65, 112-120. [CrossRef]

45. Bottenberg, H.; Masiunas, J.; Eastman, C.; Eastburn, D. Yield and quality constraints of cabbage planted in rye mulch. Biol. Agric. Hortic. 1997, 14, 323-342. [CrossRef]

(C) 2020 by the authors. Licensee MDPI, Basel, Switzerland. This article is an open access article distributed under the terms and conditions of the Creative Commons Attribution (CC BY) license (http://creativecommons.org/licenses/by/4.0/). 